\title{
GRUNDTVIG-LITTERATUR 1945-49.
}

\author{
En bibliografisk oversigt ved cand. mag. Steen Johansen.
}

\section{Indledning.}

Efter Grundtvig-Selskabets ønske skal i det følgende meddeles en bibliografisk oversigt over den i 1945-49 udkomne litteratur af og om N. F. S. Grundtvig, herunder ogsaa den vigtigste litteratur om grundtvigianismen, den grundtvigske højskolebevægelse $\mathrm{m}$. $\mathrm{m}$. - For at tilvejebringe sammenhæng med tiden før 1945 skal indledningsvis gøres opmærksom paa de vigtigste bibliografiske oversigter over den ældre Gr.-litteratur. Hovedværket er B. Erichsen og Alfr. Krarup: Dansk historisk Bibliografi I-III (1917-27). Heri findes i bd. I s. 563 f. anført litteratur om Gr.s salmer, og i samme bind s. $626 \mathrm{ff}$. litt. om grundtvigianismen og s. $724 \mathrm{ff}$. om den gr.-ske friskole og folkehøjskole. I bd. III s. 239-248 er registreret den personalhistoriske (biografiske) litt. om Gr. I Erichsen og Krarups værk anføres den til udgangen af 1912 udkomne litteratur. Fortegnelsen er derefter fortsat til og med 1940 som følger: den i 1912 og -13 udkomne historiske litteratur er registreret i Hist. Tidsskr. 8. rk. V (1914-15); litt. 1914 og -15 s. st. 8. rk. VI (1915-17), og litt. 1916-22 i 9. rk. VII (1919-25). Derefter 2 særskilte bibliografiske bind m. titlen: 》Historisk Tidsskrift. Fortegnelse over historisk Litteratur vedrørende Danmarks Historie 1923-32«. 1925-34. - [Samme] bd. II, registrerende litteraturen 1933 - 38 og udkommet 1936-43. Derefter er (1944 ff.) udkommet 2 hefter m. fortegnelse (fortløbende pagineret) over hist. litteratur 1939 og - 40. - Desuden maa nævnes den siden 1915 aarligt udkommende »Dansk TidsskriftIndex $\ll$ og den siden 1940 udgivne »Avis-Kronik-Index«. I samtlige disse fortegnelser vil man under grupperne litteraturhistorie, salmehistorie, kirkevæsen, kirkehistorie, skolevæsen og personalhistorie (biografi) let kunne finde frem til den om N. F. S. Grundtvig udkomne litteratur.

Kortere oversigter: Carl S. Petersen og Vilh. Andersen: Ill. dansk Litteraturhistorie IV (1925), 853-855 (ved Carl S. Petersen). - Dansk Udsyn 1931, 362-370 (ved Fr. Schrøder). - Vedrørende litt. om Gr.s salmer, se en lille bibliografi i Gr.: Værker i Udvalg IX (1946), s. XXVII.

Af oversigtsrecensioner over den ca. 1940(1935)-45 udkomne litteratur om N. F. S. Gr. kan især fremhæves: Hal Koch i Dansk teol. Tidsskr. 1939, 88104, 243-261; optrykt i sammes: Lidt af hvert, 1940, 84-128. - Hal Koch s. st. 1942, 45-52, 101-122. - Helge Toldberg s. st. 1946, 43-59 (jvf. hertil i det følgende under IV.f. 2: Magnus Stevns). - Helge Toldberg i Nationaltidende 27. april 48 og Bjørn Kornerup i Personalhist. Tidsskr. 1949, 172-175.

$\mathrm{Da}$ der i de nævnte oversigtsrecensioner kun i ringe grad er omtalt og recenseret de $\mathrm{i}$ anledning af den grundtvigske folkehøjskoles hundredaarsjubi- 
læum i 1944 udsendte skrifter, skal de vigtigste af disse nævnes her med det samme:

Sune Andresen: Hundrede Aar. Højskolen 1844-1944. 1944.

- (Udg.) : Nyaarsgave i Anledning af Højskolens Hundredaar. Slagelse 1944.

(J. Th. Arnfred, Lars Bækhøj, C. P. O. Christiansen): Danmarks Folkehøjskole 1844-1944. 1944.

Arne Fog Pedersen: Danmarks første Højskole og dens Mænd. 1944.

Roar Skovmand: Højskolen gennem 100 Aar. 1944.

- Folkehøjskolen i Danmark 1841-1892. Kolding 1944. - Doktordisputats. - Anmeldt bl. a. af flg.: A. Afzelius i Jyllandsposten 28. oktbr. 44, Fr. Skrubbeltrang i Berl. Aftenavis 30. oktbr. 44 og i Gr.-Studier 1948, 91-97. - Per Krarups opposition, se Gads danske Magasin 1944, 630-640.

Vald. Stenkilde: Den grundtvigske Folkehøjskole. 1944.

(Det allerede i 1940-41 udsendte store værk: Den danske Folkehøjskole gennem hundrede Aar I-II, ved Ernst J. Borup og Fred. Nørgaard, er omtalt i Kochs ovenfor nævnte recension fra 1942.)

I nærv. oversigt over Gr.-litt. 1945-49 er bøgernes trykkested København, hvor intet andet er angivet.

\section{Bibliografi.}

Steen Johansen: Bibliografi over N. F. S. Gr.s Skrifter. I. Indtil 1836. Med Forord af Georg Christensen. [Bd. II, 1837-49, udkom 1950; bd. III, 1850-72, udkommer 1951. Skal omfatte 4 bd.]

Bd. I anmeldtes bl. a. af flg.: Finn H. Blædel i »Bogrevuen og Samleren « 1948, 234 f., Ernst J. Borup i Højskolebladet 27. juli 48, J. BudtzJørgensen i Nationaltid. 21. april 48, O. Geismar i Krist. Dagbl. 20. marts 48, Søren Holm i Aalborg Stiftstid. 4. novbr. 48, Hal Koch i Dansk teol. Tidsskr. 1948, 247, Bjørn Kornerup i Personalhist. Tidsskr. 1949, 174 f.

\section{Bibliografi over oversættelser.}

Elias Bredsdorff: Danish Literature in English Translation. Orbis Litterarum V (1947), 187-257. Heri $216 \mathrm{f}$. oplysninger om skrifter af Gr. oversat til engelsk. (Hele afh. udsendt, betydeligt udvidet, i bogform 1950, m. samme titel.)

\section{Udgaver, tekstudgivelser.}

N. F. S. Grundtvig: Værker i Udvalg. Udgivet ved Georg Christensen og Hal Koch. IX, 1946. Udvalgte Salmer. Religiøse og bibelhistoriske Digte I 1810-1838. Udg. af Georg Christensen. - S. XI-XXVI: Indledning. S. XXVII: Litteratur om Gr.s Salmer.

Samme: V, 1948. [Udvalg af historiske, folkelige, politiske skrifter]. Udg. af Hal Koch. - S. VII-XVI: Indledning.

Samme: X, 1949. Udvalgte Salmer. Religiøse og bibelhistoriske Digte II 18391870. Udg. af Georg Christensen. - S. XI-XXXVIII: Indledning.

Hermed afsluttedes den i 1940 paabegyndte udgivelse af »Værker i Udvalg«. 
Grundtvigs Sang-Værk. Samlet Udgave. I. 1944 [0: 1945]. Sang-Værk til den danske Kirke.

Samme: II. 1946. Sang-Værk til den danske Kirke-Skole.

Samme: III. 1948. Salmer og kristelige Digte 1809-1843.

Samme: IV. 1949. Salmer og kristelig Digte 1844-1855. Med Efterslæt fra $1836-43$.

Denne store nyudgivelse, som skal omfatte 6 bd., besørges af et udvalg bestaaende af flg.: Th. Balslev. Ernst J. Borup. Uffe Hansen. Ejnar Skovrup. Magnus Stevns ( $\dagger$ 1950).

Bd. I anmeldtes bl. a. af flg.: O. Geismar i Krist. Dagblad 10. novbr. 45, Hagm. Hansen i Bogrevuen 1945, 288, Søren Holm i Aalborg Stiftstid. 10. decbr. 45, H. Kirk i Land og Folk 24. juli 45, Fr. Schrøder i Højskolebladet 23. novbr. 45 .

Bd. II : Fr. Schrøder i Højskolebl. 19. juli 46. - Bd. I og II af Edv. Pedersen i Aalborg Amtstid. 20. jan. 49.

Bd. III: Fr. Schrøder i Højskolebl. 18. marts 49 og i Østsjæll. Folkebl. 4. april 49.

N. F. S. Grundtvig: Danmark om hundrede Aar. [Digt.] (Kolding) [1946.]

- Den signede Dag. [Digt.] Med Tegninger af Joakim Skovgaard. Viborg [1948.]

- Paaske-Lilien. Ill. af Sven Havsteen-Mikkelsen. Udg. ved Kjeld Elfelt. [1946.]

- Paaske-Liljen. 18. Udgave. 1949.

- Velkommen igen Guds Engle smaa. En julesang. Tegninger af Herluf Jensenius. Musik af A. P. Berggreen. 1948. - Ny udg. 1949.

Grundtvigs Erindringer og Erindringer om Grundtvig. I Udvalg ved Steen Johansen og Henning Høirup. 1948.

Heri s. 13-122 et tekstudvalg af Gr.s skrifter, kommenteret af H. Høirup. - S. 113-268 et udvalg af erindringer om Gr., kommenteret af St. Johansen.

»Gr.s Erindringer . . « etc. anmeldtes bl. a. af flg.: G. Albeck i Jyllandsposten 29. novbr. 48, Ernst J. Borup i Højskolebl. 10. decbr. 48, Mogens Geismar i Fyns Tidende 8. og 9. oktbr. 48, O. Geismar i Krist. Dagbl. 2. oktbr. 48, Knud Hansen i Information 25. septbr. 48, G. Helms i Sorø Amtstid. 16. oktbr. 48, Chr. Kirchhoff-Larsen i Børsen 17. febr. 49, H. Kleener i København 4. oktbr. 48, Hal Koch i Dansk teol. Tidsskr. 1948, 247, Bjørn Kornerup i Personalhist. Tidsskr. 1949, 173 f., V. K. i Menighedsbladet 8. jan. 1950, Fr. Nielsen i Soc.-Dem. 14. novbr. 48, N. J. Rald i Præsteforeningens Blad 24. septbr. 48, D. Smith i Aalborg Amtstid. 27. oktbr. 48, H. Stangerup i Aalborg Stiftstid. 8. septbr. 48.

Langt de fleste af de i 1945-49 for første gang offentliggjorte tekster af Gr. er - hvis de ikke er fremkommet i de førnævnte større udgaver - meddelt $\mathrm{i}$ videnskabelige værker eller afhandlinger, hvori teksterne kun udgør den mindre del. Disse afhandlinger nævnes i det følgende. Af nye tekster o. lign., som væsentlig fremtræder alene, kan nævnes:

Henning Hoirup: Gr.s daglige Husandagt, efter Louise Skrikes Gengivelse. Menighedsbladet 1946, 453-455.

Pilegrimen og Pilegrimen fra Zante. Gr.s Udkast til en apologetisk Fortælling. Ved Henning Høirup. Grundtvig-Studier 1948, 7-31. 
Optegnelser af Mina Gr. den 4. August 1856. Gr.-Studier 1948, 57-59, m. oplysninger s. st. 59-62 ved Steen Johansen. - Teksten er et referat af Gr.s egen skildring af sit liv indtil 1839.

N. F. S. Gr.: »Indfald«. (Af Gr.-arkiv fasc. 327, udg. med kommentar ved Helge Toldberg.) Gr.-Studier 1949, 7-15. - Uddrag af »Indfald« er tr. i Højskolebladet 9. septbr. 49, ved H. Høirup.

Et brev fra Johan Nordahl Brun til Gr. 21. marts 1815 er tr. i Personalhist. Tidsskr. 1947, 126 f., ved Bjørn Kornerup. Jvf. hertil H. Topsøe-Jensen i Kirkehist. Samlinger 6. rk. VI (1948-50), $509 \mathrm{f}$.

\section{Om Gr.-udgaver og Gr.s efterladte papirer.}

(Georg Christensen: Grundtvigiana. Selskab for Nordisk Filologi. Aarsberetning for 1943, s. 8-10. - (Indleder med en kort kritik af udgivelsesprincipperne i »Poet. Skr.«))

Helge Toldberg: Dateringskriterier for Gr.-haandskrifter. Nord. Tidskr. för Bok- och Biblioteksväsen 1946, 107-120. - Anmeldt af Henning Høirup i Præsteforeningens Blad 8. Novbr. 46, s. 962-63 og af G. Albeck i Gr.-Studier 1949, $80 \mathrm{f}$.

- Ved vi nok om Gr.? Overraskelser fra hans papirer. Studenterkredsen 1949-50 (17. aarg.) nr. 2, s. 27-29.

\section{Samlede fremstillinger, oversigter, karakteristikker. (Alfabetisk efter forff.)}

(G. Albeck: N. F. S. Gr. Danmarks store Digtere (Red. af H. Stangerup) I (1943), 245-276).

E. L. Allen: Biskop Gr. A prophet of the North. London [1947]. I serien »Modern Christian Revolutionaries«.

Jorgen Bukdahl: Derfor bære Blus vi med Glæde. I Anledning af Hundredaret for Gr.s Adventsang »Skyerne graane - «. Askov 1947. (= Udvidet form af en artikelrække i Menighedsbladet 1947.)

- Ensomhedens Slagskygge. Politiken 30. juli 48.

Marie Christensen: Denne Mand vil aldrig dø i Danmark. København 28. aug. 47. - (I anledn. af 75-aarsdagen f. Gr.s død.)

(C. Christensen-Dalsgaard: Om Forstaaelsen af Gr. Forsøg til en Vejledning for Lægfolk. Randers 1943.)

(Noëlle Davies: Gr. of Denmark. Liverpool 1944.)

George Fridén: En man banar sig väg för Nordens ungdom. (N. F. S. Gr.) Bragd och hjältedåd nr. 84. Sthlm. 1948.

(Anton Fridrichsen: Gr. Nord. Tidskr. 1942, 265-274.)

Henning Hoirup: Gr. at læse. Menighedsbladet 1949, 262-264, 306-309.

- Breve om Gr. Menighedsbladet 1949, 449-451; 1950, 2-4, 109 f., 210212. - Udgør en diskussion m. pseudonymen »Humanus« (hvis indlæg ogsaa gengives) om Gr.s eventuelle aandsslægtskab m. d. 18. aarh. Var foranlediget af det $\mathrm{i}$ det flg. under $I V d$ nævnte radioforedrag af $\mathrm{H}$. $\mathrm{H}$.: Gr.s syn på tro og erkendelse.

(F. J. Billeskov Jansen: [en oversigt over Gr.s liv og gerning i] Dansk Daad III (1943), 138-143 (i afsnittet 》Aandsvidenskab og Digtning« 123 ff.).) 
(Jakob Knudsen: Idé og Erindring 1949, 11-28: Om Gr. I Anledning af hans udvalgte Skrifter. - (Skrevet og trykt 1908, nu for første gang optrykt.))

Svend Norrild: Dansk Litteratur fra Saxo til Kaj Munk. I-II. 1949. I bd. I 206-222 en skildring af Gr.

(Anders Norgaard: Gr. og Danmark. 1941.

- Gr. og Danmark. II. Valgmenighedspræst Anders Nørgaards sidste Skrift. Trykt efter hans Død. Kolding. [1943.])

Axel Riishøj: Den hele Gr. Tidehverv 1945, 58-50. - Var en imødegaaelse af en afh. af H. Rasmussen s. st. 1944, 98 ff. - Hertil svar fra H. R. s. st. $1945,111-116$.

IV. Specialia vedrorende Gr.s liv og forfatterskab.

a. Slægt og slægtninge.

En »Oversigt over N. F. S. Gr.s Slægt« er meddelt i »Gr.s Erindringer og Erindringer om Gr.« 1948, 302 f.

Emil Frederiksen: Ved Mindestenen for Gr.s Moder. E. Fr.: Fra Saxo Grammaticus til Hjalmar Gullberg. Essays. 1944, 40-45.

P. Hoyer-Christensen: Præstefamilien i Udby. 1947. Anm. bl. a. af E. Varming i Krist. Dagbl. 18. maj 48.

\section{b. Privatliv; personlig udvikling.}

(»Gr.s Erindringer og Erindringer om Gr.« 1948, se her foran under afsnit II.) Niels Gyde: Hvorledes Gr. blev Jyde. Sorø Amtstid. 4. aug. 45. - (Om Gr.s ophold i Tyregod.)

Gustav Albeck: Gr.s slemme Skolegang. Aarhus 1945.

Emil Frederiksen: Den unge Gr. og andre Essays. 1948. Heri s. 9-120 6 essays om Gr.s liv (og forfatterskab) fra hans barndom i Udby og til og med hans tid som kapellan i samme by $(1811-13)$; s. $121-128$ et essay om Gr.s Sakse-myte, jvf. i det flg. u. $e$ 2.

Da Gr.-afsnittene hører til den vægtigste del af bogen, skal et udvalg af anmeldelserne anføres her:

G. Albeck i Jyllandsposten 29. novbr. 48 og i Gr.-Studier 1949, 87-89, O. Geismar i Krist. Dagbl. 11. maj 48, Søren Holm i Aalborg Stiftstid. 4. novbr. 48, Bernh. Jensen i København 19. maj 48, Tom Kristensen i Politiken 18. maj 48, Fr. Nielsen i Soc.-Dem. 30. septbr. 48 og samme: Den unge Gr. Smaa kommentarer til en essaysamling. Gads danske Magasin 1948, 508-518, Paul V. Rubow i Berl. Aftenavis 14. april 48, F. Vendelhaven i Vestkysten 10. juli 48.

Christianshavns Dottreskole 1799-1949. 1949. [Mindeskrift.] Heri flere spredte oplysninger om Gr. som medlem af skolens direktion 1824-27.

(H. J. H. Glædemark: N. F. S. Gr.s Nedlæggelse af Præsteembedet i 1826. Kirkehist. Samlinger 6. rk. III (1939-41), 201-304. - Jvf. hertil Steen Johansen i Gr.-Studier 1949, 90 f. (hvor der s. 90, 1. 3 f. n. beklageligvis er udfaldet 3 ord: »ikke har benyttet« $>$ »ikke i tilstrækkelig grad har benyttet« osv.).) 
(Det bevægede aar 1844 i Gr.s liv gav bl. a. anledning til flg. udførlige artikel af H. Rosendal: Et Aar af Gr.s Liv. 1844. Højskolebladet 1944, 306315. - Om Gr.s digteriske produktion (spec. erot. digte) i 1844, se Georg Christensen: Grundtvigiana. Selskabet $f$. Nordisk Filologi. Aarsberetning fra 1943, 8-10.)

\section{c. Litterært eller personligt forhold til enkeltpersoner (eller disses forhold til Gr.).}

Jorgen Larsen: H. N. Clausen. Hans Liv og Gerning. I. Aarene 1793-1848. 1945. - Heri 146 ff. om H. N. Cl. og Gr. - Jvf. hertil L. Bergmann i Kirkehist. Saml. 6. rk. V (1945-47), 325-332 (om Cl. og Gr.s Kirkens Gienmale).

Henning Hoirup: Menneske først - - En Gr.-Holberg Studie. Vartovbogen 1947, 124-157. Litteraturhenvisninger s. st. 156 f. Anmeldt af G. Albeck i Gr.-Studier 1949, 89 f. og H. Toldberg i Nationaltid. 27. april 48. - (Om Gr.s forhold til Holberg, belyst gennem nogle citater, se ogsaa EhrencronMüller: Forf.-lexikon XI (1934) 141-143.)

Sv. Falsig Pedersen: N. F. S. Gr.s og Julius Langbehns Indflydelse paa Johs. V. Jensens Ungdomsudvikling. Orbis Litterarum III (1945), 188-208. Jvf. hertil L. Nedergaards indsigelse i Danske Studier 1948, 142-148.

E. L. Allen: Gr. and Kierkegaard. The Congregational Quarterly, July 1946. - Jvf. Toldberg i Nationaltid. 27. april 48.

Soren Prahl: Gr. og Kierkegaard. Danskeren 1949 (11. aarg.) nr. 2, s. 3-5. (David L. MacKaye: Gr. and Kold. The American-Scandinavian Review 1942, 229-239.)

Johs. Lauritzen: Luther og Gr. Menighedsbladet 1945, 69 f. - - (I anledn. af R. Prenter: Spiritus creator. Studier i Luthers Theologi. 1944.)

Om Maeterlinck's forhold til Gr. er givet nogle oplysninger af Johs. Lehmann i hans mindeartikel ved M.s død i Berl. Tid. 9. maj 49.

Svend Hauge: Studier over D. G. Monrad som religiøs Personlighed. 1944. (Disputats.) - Heri 232-241: M.s forhold til grundtvigianismen. Jvf. hertil L. Bergmann i Kirkehist. Samlinger 6. rk. V (1945-47), 100-110 (om M.s forhold til Gr.).

N. Marinus Jensen: To hovedskikkelser fra gennembrudsaarene 1848-49. Højskolebladet 1949, 251-253. - (En sammenstilling af Monrad og Gr.)

(N. M. Plum: Mynster og Gr. Gads danske Magasin 1939, 359-384.)

Seren Prahl: Mynster og Gr. Danskeren 1949 (11. aarg.) nr. 1, s. 4-6.

H. Toldberg: Jens Moller som æstetiker og mytolog. Danske Studier 1945 (udk. -47), 49-96. - Heri 71-77 en fremstilling af Gr.s opgør m. J.M.

Einar Boyesen: Gr., Hartvig Nissen og skandinavismen. Nord. Tidskrift 1946, 89-103.

H. P. Hansen: Peter Rordam som Politiker. Højskolebladet 1948, 363 f., 378380, 415 f., 437 f. - Heri ogsaa om Gr. og Rørdam.

H. Toldberg: Nugent Wade i Helsingør. En engelsk præsts møde med Gr. og Mynster. Gr.-Studier 1948, 42-56. - Anmeldt af P. Augustinus i Menighedsbl. 1949, 270.

C. I. Scharling: Gr.s Strid med H. C. Ørsted. Kirken og Tiden 1945, 33-43. 


\section{d. Teologiske, filosofiske og psykologiske sporgsmaal vedrorende $\mathrm{Gr}$.}

(Holger Rasmussen: Gr.s Sakramentsyn og hans folkelige Grundtanke. Tidehverv 1944, 98-105.)

D. Smith: Gr.s Daabsopfattelse. Menighedsbladet 1947, 262-265.

(Henning Heirup: En Fornyelse af Luthers Katekismus i Gr.s Aand mulig? Fyns Tidende 8. novbr. 42.)

(Henning Høirup: Var Gr. »en Sværmer«? Fyns Tidende 6. jan. 43. - Mod Chr. Bartholdys artikler »Moderne Sværmerier« i Indre Missions Tidende 1943, nr. 47-49.)

C. I. Scharling: Evighedshaabet og det jordiske Liv hos Gr. Julebogen. (Udg. af Kirkeligt Samfund.) 1948, 19-28.

R. Prenter: Gr.s Syn paa Forkyndelsen. Gr.-Studier 1948, 63-78. - Anm. af P. Augustinus i Menighedsbl. 1949, 271.

H. Høirup: Gr.s Syn paa Tro og Erkendelse. Modsigelsens Grundsætning som teologisk Aksiom hos Gr. 1949. (Skrifter udg. af Gr.-Selskabet. I.) (Doktordisputats.)

Anmeldtes bl. a. af flg.: P. Augustinus i Menighedsbladet 1949, $240 \mathrm{f}$, J. Busk i Aalborg Amtstid. 22. maj 49, L. B. Fog i Fyns Stiftstid. 17. febr. 49, Vill. Grønbak i Jyllandsposten 19. febr. 49, Søren Holm i Berl. Aftenavis 17. febr. 49 og i Dansk teol. Tidsskr. 1949, 81-102, V. H. i Nord. Tidskr. 1949, 356 f., J. Juul i Menighedsbladet 1949, 238 f., Chr. Kirchhoff-Larsen i Børsen 17. febr. 49, Hal Koch i Højskolebladet 22. april 49, Peter P. Rohde i Information 16. febr. 49, C. I. Scharling i Gr.-Studier 1949, 91-95 og i Dansk Udsyn 1949, 284-287, K. Thaning i Præsteforeningens Blad 1949, 479-484.

- Gr.s Syn på tro og erkendelse. Radioforedrag langfredag den 15. april 1949. Menighedsbladet 1949, 158-162. - Foranledigede de her foran under III omtalte »Breve om Gr.« I-IV, af samme.

(P. Seidelin: Eschatologien i Gr.s Salmedigtning. - Se i d. flg. u. f 1.)

P. Logstrup: »Gudsfrygt styrker Land og Rige«. Sorø Amtstid. 31. marts 45. - (Om Gr.s stilling til forholdet mellem kristendommen og det verdslige liv.)

H. Hoirup: Hvad Gr. mente om de kvindelige Præster. Menighedsbladet 1948, 190-192 og Fyns Tidende 29. maj 48.

P. Schindler: Gr. som Existentialist. Catholica 1948, 1-11.

W. Michelsen: 》Om menneskets vilkaar« - en manuskriptgruppe i N. F. S. Gr.s arkiv. Nord. Tidskr. 1946, 378-395. - (Om Gr. som psykolog.)

V. Gronbæk: Om en Afhandling af Gr. Gads danske Magasin 1946, 493504. - (Om Gr.s afh. »Om Menneskets Vilkaar«.)

O. Geismar: Det er farligt for tosser at tænke. Krist. Dagblad 23. marts 49. - (Om Gr. og rationalismen.)

J. Bukdahl og P. Engberg: Gr. og Naturvidenskaben. Askov 1945.

N. C. Jensen: Gr. og Naturvidenskaben. København 25. jan., 27. jan., 28. jan. 47. 
e. Litterære og filologiske behandlinger af dele af Gr.s forfatterskab

(bortset fra salmerne).

1.

(Alfabetisk efter forff.)

Poul Engberg: Oplysningstidens og Romantikkens Historiesyn. Dansk Udsyn 1949, 30-43. - (Afh., inspireret af C. I. Scharlings nedenfor nævnte bog 》Gr. og Romantiken « 1947.)

Villiam Gronbxk: Gr. og tysk Aandsliv. Jyllandsposten 17. april 46.

[Kr. Kristensen] Hessel[ager]: Gr. som Historiker set i amerikanske Briller. København 26. aug. 48. (= Interview m. prof. Kemp Malone.)

Eigil Hultberg: Gr.s Syn paa Idræt og Kunst. Krist. Dagblad 21. febr. og 23. febr. 45.

C. I. Scharling: Gr. og Romantiken. Belyst ved Gr.s Forhold til Schelling. 1947.

Anmeldtes bl. a. af flg.: G. Albeck i Jyllandsposten 22. marts 48, P. Augustinus i Menighedsbladet 1949, 201 f., Ernst J. Borup i Højskolebladet 5. decbr. 47, Sv. Brandt i Vejle Amts Folkebl. 11. marts 48, J. Bukdahl i Menighedsbladet 1948, 126-128, J. Busk i Aalborg Amtstid. 15. novbr. 47, Poul Engberg i Dansk Udsyn 1947, 300-302, E. Frederiksen i Berl. Aftenavis 8. novbr. 47, O. Geismar i Krist. Dagbl. 3. decbr. 47, Knud Hansen i Information 27. jan. 48, G. Helms i Fyns Venstrebl. 23. novbr. 47, Søren Holm i Nationaltid. 12. novbr. 47, Henning Høirup i Fyns Tidende 23. decbr. 47, Bernh. Jensen i København 1. decbr. 47, Hal Koch i Politiken 27. decbr. 47, Paul Krüger i Orbis Litterarum VI (1948), 308-310, W. Michelsen i Gr.-Studier 1948, 79-91. M.s anmeldelse blev genstand for særskilte betragtninger af J. Bukdahl i Dansk Udsyn 1948, 289 f., hvad der fremkaldte en modartikel af W. M. s. st. 1949, 129 f. og en efterskrift af J. B. s. st. 130-134. - Fr. Nielsen i Soc.-Dem. 6. maj 48, H. Toldberg i Gymnasieskolen 1947, 629 f., F. Vendelhaven i Vestkysten 10. juli 48.

(Roar Skovmand: N. F. S. Gr. [som historiker.] Erich Bach: Danske Historieskrivere. 1942, 51-64.)

H. Toldberg: Oplevelsens betydning i Gr.s poesi. Orbis Litterarum III (1945), 59-107. - Jvf. hertil G. Albeck i Gr.-Studier 1949, 79 ff., P. Krüger i Orbis Litterarum IV (1946), 308 og W. Michelsen s. st. VI (1948), 151158.

- Gr. som filolog. (Teologiske Studier. Dansk teologisk Tidsskrift II. Afd. Nr. 8). 1946.

Anmeldtes bl. a. af flg.: G. Albeck i Gr.-Studier 1949, 80-85, H. Høirup i Præsteforeningens Blad 1947, 140-143, Ragna Lorentzen i Gymnasieskolen 1947, $168 \mathrm{f}$.

- Stadier i Gr.s forfatterskab. Acta Philologica Scandinavica, 19. aarg. (1947-50), 143-178.

Anm. af G. Albeck i Gr.-Studier 1949, 85-87.

- Gr. belyst af en moderne anglist. Gr.-Studier 1948, 98-102. - Udgør en recension af 3 afhandlinger af den amerik. prof. Kemp Malone (»Gr.s Philosophy of History«, »Gr. as Beowulf Critic«, »Gr. on Paradise Lost«.) 
2.

(Kronologisk efter de behandlede skrifter af $\mathrm{Gr}$.)

G. Albeck: Gr. og Jylland. (Ledetraad ved folkelig Universitetsundervisning Nr. 201.) 1946. - (Om digte, hvori Gr. mindes sin jyske barndom, samt om andre digte af Gr. om Jylland.)

H. Toldberg: Ved vi nok om Gr.? Overraskelser fra hans papirer. Studenterkredsen 1949-50 (17. aarg.), 27.-29. - (Heri bl. a. om Gr.s planer (1807) til en almueoplysning, hans første højskoleplaner (1827) og første planer (1810) om at oversætte Saxo.)

G. Albeck: Indskriften paa Oddens Mindestøtte. [1809-10.] Gr.-Studier 1948, $32-41$.

P. Østergaard: Gr.s »Paaskeliljen«. [1817.] Dansk Politik. Aarg. 13, 1945, nr. 12.

Johs. Johansen: Bondeblomst fra Landsbyhave. Aarhuus Stiftstid. 20. april 46. - (Om »Paaskeliljen«.)

E. Frederiksen: Gr.s Sakse. [1818-22.] E. Frederiksen: Fra Saxo Grammaticus til Hjalmar Gullberg. 1944, 27-39.

- Gr.s Sakse-Myte. E. Frederiksen: Den unge Gr. og andre Essays. 1948, 121-128.

Johan Jensen: To Fædrelandssange. Fortids Veje. Aarg. 5, 1947, 316-322. (Bl. a. om »Langt højere Bjerge - 1820 .)

Niels Skriver Svendsen: Gylden-Aaret. Højskolebladet 4. jan. 46. - (Om » $\mathrm{Nu}$ skal det aabenbares« 1834.)

(Knud Berlin: Gr.s Mands Minde. Gr. som historisk Kritiker og historisk Profet. 1942. - Om Mands Minde-foredragene 1838.)

P. Augustinus: Natur og Kunst. Menighedsbladet 1945, 109-111. - (Om »Sønner mine, lige kjære«, 1839.)

Aug. F. Schmidt: Gr.s og Aakjærs himmelbjergdigte. [Omkr. 1840.] Skive Folkeblad 13. oktbr. 49.

Anton Mikkelsen: Gr. og Folkevisen 1847. Menighedsbladet 1947, 200-202.

Ernst J. Borup: Gr.s ugeblad »Danskeren«. [1848-51.] Krist. Dagbl. 23. juni 49.

Ejnar Skovrup: Omkring Gr.s Digtning i 1848. Vartovbogen 1948, 119-134.

Frode Aagaard: Fæderneland ved den bølgende Strand. Fyns Tidende 5. marts 48. - (Om Gr.s digt fra 1848.)

Holger Andersen: 》Fædreneland ved den bølgende Strand«. Fyns Venstrebl. 6. april 48. - Hertil s. st. 9. april 48 af Randi Poulsen. - (Som forrige.)

Erik Appel: Fæderneland ved den bølgende Strand. Menighedsbladet 1949, 11-13. - (Som forrige.)

Poul Engberg: Danmarks engel. Et hundredårsminde. Menighedsbladet 1949, 2-4. - (Om slutningsdigtene i de 3 første aargange (1848-50) af »Danskeren $\ll$.)

Gudm. Schütte: Gr.s Sandsagn om Danmark. Skive Folkeblad 28. oktbr. 46. - (Om Gr.s spaadomsdigte fra »Danskeren«.)

Henning Hoirup: Kærlighed til Fædrelandet. Om Gr.s Digt »Den danske Nødvendighed«. [1853.] Fyns Tidende 2. aug. 45.

P. Augustinus: Tid og Evighed. Menighedsbladet 1945, 45 f. - (Om Gr.s digt $1856 \mathrm{~m}$. næunte titel.)

Kr. Nygaard: Dansk Ravnegalder. [1860.] Fyns Venstreblad 2. jan. 45. 
f. Gr.s salmer.

1.

Om salmerne i almindelighed.

(Alfabetisk efter forff.)

Marie Christensen: Gr. og Salmedigteren Montgomery. Flensborg Avis 15. maj og 17. maj 46.

O. Geismar: Sang-Værk til den danske Kirke. Vartovbogen 1947, 86-98.

H. Graversen: Gr.s Salmedigtning. Historisk og kirkelig belyst. 1948.

Uffe Hansen: Gr. og Salmebogen. Prøveheftet 1845. Højskolebladet 1945, 398-401.

- Gr.s Festsalmer. Højskolebladet 1945, 427 f.

- Med Gr. i Kirke. Julebogen. (Udg. af Kirkeligt Samfund.) 1947, 101-113. (Om Gr.s salmer.)

Ebbe Juul: Kirkesynet i Gr.s Salmer. Dansk Kirkeliv 1947, 85-95.

J. Kjær: Gr.s Salmer. Graasten 1948.

K. Olesen Larsen: Om Gr.s Salmer. Tidehverv 1947, 25-33, 40-50.

Kj. Lawaetz: Mangler Gr.s Salmetone Ydmyghed? En Kritik af en Kritik. Menighedsbladet 1945, 101-103. - (Foranlediget af en art. af Ejnar Thomsen i Dansk Kirkeliv 1944, 79-87: Det grundtvigske Salmebogsforslag.)

N. Olav Nielsen: Omkring et Salmehefte. [Om festsalmerne, $1845 \mathrm{ff}$., Sangværket m. m.] Krist. Dagbl. 24. decbr. 45.

Salomon Nielsen: En Mindedag i dansk Salmesangs Historie. Sorø Amtstid. 27. decbr. 45. - (Emne omtrent som foregaaende.)

F. Paludan-Müller: Træk af Billedstil og Ordvalg i Gr.s Salmedigtning. Kirken og Tiden 1947, 1-11.

A. Bartholdy Moller: Ordet, Badet og Bordet. Dansk Kirkeliv 1947, 74-84.

P. H. Petersen: Kun hos Gr. Menighedsbladet 1946, 75. - (Om ordet skun « i visse salmer.)

P. Seidelin: Eschatologien i Gr.s Salmedigtning. Festskrift til Jens Nørregaard d. 16. Maj 1947. 1947, 254-271.

Jvf. hertil Toldberg i Nationaltid. 27. april 48 (og C. I. Scharling i Gr.-Studier 1950, $7 \mathrm{ff}$.).

Magnus Stevns: Gr. og Kingos Salmer. Gr.-Studier 1949, 16-34. - Optrykt i sammes: Fra Gr.s Salmeværksted, 1950, 86-105.

P. Østergaard: Gr. og Julen. Østsjall. Folkeblad 17. decbr. 45. - (Om Gr.s julesalmer.)

Olaf Moe: Svensk og dansk-norsk salmetradisjon. Streiftog i den svenske salmebok av 1819 og 1937.

Tidsskr. for Teologi og Kirke, bd. 14 (Oslo 1943), 124-132. - (Om den $i$ nyeste tid stedfundne tilnærmelse mellem svensk og dansk-norsk salmetradition, m. oplysninger om forekomsten af Gr.-salmer i den nye svenske salmebog.) 
Registrering af indlæg i diskussionen om den nye salmebog (herunder spørgsmaalet om udeladelse eller medtagelse af visse Gr.-salmer) har maattet udelades her. I 1944 udsendte »Det gr.-ske Salmebogsudvalg《 et udkast m. titlen »Dansk Salmebog. Forslag til en ny autoriseret Salmebog for Kongeriget Danmark «. Se om dette forslag bl. a. den ovenfor (u. Lawaetz) omtalte art. af Ejnar Thomsen.

Enkelte salmer.

(Alfabetisk efter hver salmes førstelinie.)

Aug. F. Schmidt: Dejlig er den Himmel blaa. Danske Studier 1944, 91-96. - 》Dejlig er den himmel blaa«. Fyns Venstrebl. 23. decbr. 48.

Vilh. Andersen: Et Tiaar. 1945. Heri 74-80: Den nordiske Dagvise. (Tildels om »Den signede Dag - «.)

Aug. F. Schmidt: Den gamle Dagvise og Gr. Dansk Politik. Aarg. 14 (1946), nr. 51. - (Om »Den signede Dag - «.)

Magnus Stevns: Bemærkninger i Forbindelse med Helge Toldbergs »Moderne Gr.-Litteratur«. Dansk teol. Tidsskr. 1946, 191 f. - (Dels om »Den signede Dag - (om fortolkningen af et par lin.), dels om »Op dog, Zion, - (forstaaelsen af »Kæmpeskridt«.))

Hans Pedersen: Det er saa yndigt at følges ad -. Dansk Politik. Aarg. 13 (1945), nr. 38.

(Et spørgsmaal vedrørende en enkelthed i »Guds Helligaand, vor Igenføder «, se Kristine Friis i) Menighedsbladet 1946, 75.

A. Bartholdy Moller: Omkring en Salme af Gr. Krist. Dagbl. 20. oktbr. 48. (Om »Herrens Røst, som aldrig brister«.)

K. J. Jensen: »Mennesket først, Kristen saa《. Krist. Dagbl. 14. aug. 47. Hertil s. st. 4. septbr. 47 en art. af Uffe Hansen, hvorefter et par bemærkninger s. st. 13. septbr. 47 af I. Sveistrup.

H. Høirup: Menneske først -. En Gr.-Holberg Studie. Vartovbogen 1947, 124-154.

Uffe Hansen: Nat i Østen. Menighedsbladet 1946, $452 \mathrm{f}$. - (Om »Nat i Østen er ej saa lang«.)

H. Toldberg: Gr.s Julenatssalme. Nationaltid. 24. decbr. 46. - (Om »Nat i Østen .... etc.)

C. S. Nygaard: En hundredogfemaarig. København 8. septbr. 49. - (Om »Nu falmer Skoven ......)

P. Østergaard: To Høstsalmer. Aalborg Stiftstid. 14. septbr. 48. - (Om $\gg \mathrm{Nu}$ falmer Skoven . . « og Jak. Knudsens »Vi pløjed, og vi saa'de«.)

P. Ostergaard: Lidt om et Par Høstsalmer og deres Historie. Dansk Politik. Aarg. 14 (1946), nr. 35. - (Som forrige.)

F. Paludan-Müller: »Og klar du Jordklimpen i Solglansen mild«. Danske Studier 1945, 148-150. - (Om »O Kristelighed ... . .)

(Om »Op dog, Zion ... «, se ovenfor u. M. Stevns.)

Ernst Fr. Hansen: Gr.s Sang om den gule Bondeblomst i Udbys Haver. Indre Missions Tidende 1945, 76-77. - (Om »Sig mig, Blomst, hvad vil du her! ... « (indledn. t. Paaske-Liljen).)

Aug. F. Schmidt: Velkommen igen -. Fyns Venstreblad 22. decbr. 49. 


\section{g. Gr. og England.}

(Alfabetisk efter forff.)

T. Driffield-Hawkin: When Gr. Worked at Exeter. »Denmark«, London, Aug. 1948.

Henning Heirup: Er England ved at opdage Gr.? Fyns Tidende 6. maj 49.

P. G. Lindhardt: Gr. og England. Aalborg Stiftstid. 19. aug. 48.

- Gr. i England. Danskeren. Aarg. 11 (1949), nr. 5, s. 2-4.

H. Toldberg: Gr. og de engelske antikvarer. Orbis Litterarum V (1947, ग: 1948), 258-311.

- Gr.s Mellemværende med de engelske Lærde. Nationaltid. 29. april 49.

- Gr. og Puseys Oxfordbevægelse. Kirkehist. Samlinger 6. rk. VI (1948 $-50), 272-283$.

h. Gr. som politiker.

(Alfabetisk efter forff.)

Frode Aagaard: Gr. paa den grundlovgivende rigsforsamling. Aalborg Amtstid. 11. april 49.

Ernst J. Borup: N. F. S. Gr. Billeder af Rigsdagens Historie. I (1947), 141156, med illustrationer. Ogsaa som særtryk m. titlen: Gr. som Politiker. (Uden illustr.)

G. Brier: »Kongeaand [!] og Folkestemme«. I. Aalborg Amtstid. 16. juni 48. - Fortsat s. st. 17. juni med: Gr. og den nationale Kamp. II., og 19. juni: Gr. og Grundloven. III.

Helge Grell: Et Par udenrigspolitiske Synspunkter hos Gr. Menighedsbladet $1945,337 \mathrm{f}$.

H. P. Hansen: Folketingskandidat N. F. S. Gr. Højskolebladet 1949, 504-506. Ogsaa i »Vejen frem«. Aarg. 15 (1949), 5-7.

- Folketingsvalg i Præstøkredsen. Antvorskov Højskoles Aarsskrift 1946, 19-47. - (Heri bl. a. ogsaa om Gr.s valg 1848 og -49.)

(Sv. Henningsen: Gr. som Politiker. (Ledetraad ved folkelig Universitetsundervisning Nr. 117). 1941.)

(Vilh. Krarup: Gr. og Nationalliberalismen. Tidehverv 1943, 67-72.)

H. C. Nielsen-Svinning: Gr. som Politiker. Randers Dagblad 8. jan. og 9. jan. 46.

Kaj Thaning: Gr. og den grundlovgivende Rigsforsamling. Gr.-Studier 1949, $35-73$.

i. Gr. og Sonderjylland.

(Alfabetisk efter forff.)

Frede Bording: Gr. og Sønderjylland. (Dannevirkekredsens Flyveskrifter 1). Sorø 1945.

Anmeldtes bl. a. af Ernst J. Borup i Menighedsbladet 1946, 70-72; hertil bemærkning af Fr. B. s. st. 102. - Ogsaa anmeldt af Fr. Schrøder i Højskolebladet 1946, 61-63. Hertil svar fra Fr. B. s. st. 82 f., og et indlæg af Holger Schrøder s. st. $94 \mathrm{f}$. Gensvar fra Fr. Schr. $102 \mathrm{f}$., hvorefter svar fra Fr. B. 118 f., fra Fr. Schr. 127 f. og fra Fr. B. 140.

W. Michelsen: N. F. S. Gr. og Sønderjylland. Nord. Tidskr. 1945, 104-115. - (Nævnt i Toldbergs recension fra 1946, jvf. her foran: indledningen.)

Axel Riishøj: Gr. og Sønderjylland. Vartovbogen 1949, 80-111. Litteraturhenvisninger s. st. 159. 
j. Gr. og Vartov.

(Skat Arildsen: Studier i Vartovs Menigheds og Kirkes Historie. I. N. F. S. Gr.s første Tid som Præst ved Vartov Hospital. Historiske Meddelelser om København. 3. rk. III (1938-39), 521-549.)

Uffe Hansen: Gr. i Vartov. De grundtvigske Fri- og Valgmenigheder. En hist. Oversigt . . . ved Asger Højmark og Uffe Hansen. 1944, 39-52.

I 1947 købte »Kirkeligt Samfund af 1898« Vartov af Københavns Kommune. Til støtte for Kirkeligt Samfund's økonomi paabegyndtes udsendelsen af aarsskriftet »Vartovbogen«, hvoraf bd. I kom 1947, II 1948, tredie bind 1949 (romertalnummerering paa bindet fjernet) osv. - I dette aarsskrift findes afhandlinger om Gr., om Vartov bygning, grundtvigianismen osv., hvoraf flere er anført paa deres pladser i nærv. bibliografi.

k. Gr. som pædagog og folkeopdrager; højskolen.

(Alfabetisk efter forff., uden forseg paa yderligere gruppering.)

(Skrifter om højskolen i anledn. af hundredaarsjubilæet 1944, se her foran s. $115 \mathrm{f}$.)

Ernst J. Borup: Fritz Wartenweiler. En gammel Ryslinge-Elev og -Lærer. Ryslingebogen 1949, 35-40.

Poul Engberg: Nordens Højskoler. Perspektiver og Aktualiteter. 1948. Anmeldt f. eks. af J. Bukdahl i Dansk Udsyn 1948, 291 f. Jvf. ogsaa Folke Trier Hansen i Højskolebl. 1948, $254 \mathrm{f}$.

Johs. Fog: En grundtvigsk Kirkeskole. Menighedsbladet 1946, $150 \mathrm{f.}, 156 \mathrm{f}$.

Henning Høirup: En fri dansk grundtvigsk Lærerskole. Fyns Tidende 28. april 43. - (I anledn. af E. Skovrups pjece: En fri dansk lærerskole, Odense 1943.)

J. Christmas Moller og Katherine Watson: Education in democracy. The Folk high schools of Denmark. London. 1944.

Anm. f. eks. af H. Toldberg i Nationaltid. 27. april 48.

H. C. Nielsen-Svinning: Gr.s Højskoleforedrag paa »Marielyst« 1865-66. Fyns Venstreblad 6, april 46.

Arne Fog Pedersen: H. N. Clausen og Folkehøjskolen. Rødding Højskoles Aarsskrift 1946, 31-36.

Fr. Skrubbeltrang: Den danske Folkehøjskole. 1946.

Elisabeth Sontag: N. F. S. Gr. Erzieher seines Volkes. Bern 1946.

Anmeldt bl. a. af Ernst J. Borup i Højskolebl. 27. juni 47, af H. Toldberg i Nationaltid. 27. april 48 og af Wilh. Sjöstrand i Erasmus I (1947), sp. $651 \mathrm{f}$.

(Kaj Thaning: En Grundtvigkritik. Tidehverv 1942, 19-24. - (Om Gr.s skoletanker.)) 
1. Gr. og norden, den nordiske tanke; Gr. og danskheden.

(Alfabetisk efter forff.)

(Alf Ahlberg: Gr. och nordisk uppfostran. Nord. Tidskr. 1943, 417-429.)

Jorgen Bukdahl: Videnskab og Aandsliv. Omkring Gøteborgtanken og Nutiden. Dansk Udsyn 1945, 77-97. - Foranlediget af C. P. O. Christiansen og H. Kjær: Gr., Norden og Göteborg, 1942, og G. Albeck: Gr. og Norden, 1942.

(C. P. O. Christiansen: Gr., den nordiske Aand og den nordiske Sandhed af i Dag. Gads danske Magasin, 1942, 1-14.)

C. P. O. Christiansen: Gr.s Gøteborgtanke, Gøteborgskolen og Gøteborgkurserne. Studenterkredsen 1947-48 (15. aarg.), $29 \mathrm{f}$.

Poul Engberg: Nordens folkelige Opgave i Verdenshistorien. Dansk Udsyn $1945,20-36$.

(Gunnar Furuland: Gr. - den nynordiska tankens fader. Västervåg. Organ för Västkustens ungdomsskola och elevförbund 1944. (Afhandling.) Heri ogsaa henvisninger til et par andre svenske afh. om Gr. og norden.)

(Greta Hedin: Nordiska uppfostringsideal. Nord. Tidskr. 1943, 342-353. Heri bl. a. ogsaa om Gr.)

Otto Holmgaard: Den danske Sag. Gr.s Fremtidsudtalelser om Danmark. 1945. Knud Hylleberg: Gr.s nordiske Syn. Vestkysten 12. maj 45.

Henning Høirup: Nordens Profet. Gr. set med svenske Øjne. Fyns Tidende 14. septbr. 45.

Albert Lilius: Nordiska Gestalter ur bildningsarbetets historia. 1946. - Heri et Gr.-afsnit, jvf. H. Toldberg i Nationaltid. 27. april 48.

W. Michelsen: Gr. og Danskheden. Nord. Tidskr. 1945, 1-16.

m. Gr. og det menneskelige, det sociale.

Jorgen Begh: Bliver Gr. europaisk. Dansk Udsyn 1948, $185 \mathrm{f}$.

Oluf Olsen: Sct. Grundtvig? Menighedsbladet 1946, 86-90.

R. Prenter: Gr.s Syn paa Mennesket. Kirke og Kultur 1948, 209-226.

Axel Riishøj: Gr.s Tanker om det menneskelige. Menighedsbladet 1946, 349 f., 356-358.

Fr. Schroder: Gr. og det sociale. Menighedsbladet 1946, 427-429.

n. Grundtvigianismen $i$ fortid, nutid og fremtid.

(Alfabetisk efter forff., uden forseg paa yderligere gruppering.)

Nyere fagværker, hvori der ogsaa bidrages til grundtvigianismens historie, er: H. J. H. Glædemark: Kirkeforfatningsspørgsmaalet i Danmark indtil 1874. En historisk-kirkeretlig Studie. 1948 (Doktordisp.); Hal Koch: Danmarks Kirke gennem Tiderne. 4. udg., 1949; H. Stangerup: Kulturkampen. I-II. 1946.

Agnete Aabjerg: Omkring det grundtvigske. Krist. Dagbl. 22. juni 49.

Helge Aagaard: Det grundtvigske Indslag i dansk Kirkeliv. Vestkysten 23. decbr. 46.

Jakob Busk: To kirkelige Retninger. Aalborg Amtstid. 5., 6. og 8. april 48. (Om grundtvigianismen og Indre mission.)

Jorgen Begh: Grundtvigianismens Fremtid. Information 24. april 48. 
C. J. Hammer: Minder fra en grundtvigsk Bevægelse i firserne. Krist. Dagbl. 14. juni 49.

Uffe Hansen: Gr.s Menighedssyn. De grundtvigske Fri- og Valgmenigheder. Ved Asger Højmark og Uffe Hansen. Odense 1944, 15-22.

- Den grundtvigske Vækkelse. Nysnævnte bog 23-32.

Birger Isaksen: Af fynsk Grundtvigianismes Historie. Fyns Venstreblad 12. aug. 45.

Andreas Jensen: Grundtvigianismen i Vendsyssel og den Henriksen'ske Bevægelse. Hjørring 1945.

Jorgen Jensen: Det grundtvigske i Nutiden. Vartovbogen 1948, 135-146. Hertil Agnete Aabjerg i Højskolebladet 1949, 29 f. og Fr. Schrøder s. st. 63-65; J. Jensen s. st. 82 f.; A. Aabjerg 83; Arne Brandt Pedersen 105; Fr. Schrøder 113-115.

Erik $H$. Knudsen: Er der idag en grundtvigsk Bevægelse? Menighedsbladet $1948,87 \mathrm{f}$.

Johs. Lauridsen: Grundtvigianismen og det forargende Evangelium! Fyns Venstreblad 8. decbr. 49.

P. G. Lindhardt: Den danske Folkekirke - upartisk betragtet. Frie Ord II (1947), 337-351. - (Bl. a. om engelsk indflydelse paa Gr.s kirketanker.)

P. G. Lindhardts artikler (i Menighedsbladet 1949) om grundtvigianismen indgik senere i udvidet, endelig form $\mathrm{i}$ hans bog »Vækkelser og kirkelige retninger i Danmark «, 1951.

Johs. Monrad: Gr. nu. Højskolebladet 1945, 269 f.

Aage Moller: Nordiske Myter. (Odense) 1947. Denne bog er »et forsøg paa at gengive Gr.s menneskelige og folkelige syner ud fra hans mytologi af 1832 (forordet). I indledningen (s. 9-16) gives en oversigt over højskolegrundtvigianismens historie.

Bogen fremkaldte bl. a. flg.: Holger Kjær: Aage Møllers nordiske Mytologi. Højskolebl. 1948, 25-29 (en rettelse s. st. 48). Hertil Folke Trier Hansen s. st. 104 f., H. Kjær 156 f., F. Trier Hansen 172-174, H. Kjær 213. - Jørgen Bøgh: Mennesket og Myten. Nogle Bemærkninger til Aage Møllers »Nordiske Myter«. Dansk Udsyn 1948, 25-34. J. Bukdahl s. st. 291.

Holger Schroder: Det grundtvigske Nederlag. Frie Ord III (1948), 279-296. Max Lybeck Sorensen: Grundtvigianismen og Kirken i Dag. [Interview med den designerede kirkeminister provst Carl Hermansen.] Nationaltid. 8. novbr. 45.

Fr. Schroder: Lavkirkelig Grundtvigianisme. Menighedsbladet 1945, $13 \mathrm{f}$.

Randi Stendevad: Grundtvigsk renessance? Kirke og Kultur 1949, 504-508.

(Kaj Thaning: Er Grundtvigianismen ufolkelig? Studenterkredsen. 10. Aarg. (1942-43), 75 ff.).

- Milieu eller Kirke. Højskolebladet 1947, 32 f., 43-45 (aftrykt efter »Studenterkredsen«). Hertil J. Busk s. st. 11 f. og Thaning s. st. 57 og Busk 68. Andre senere indlæg i samme blad nævnte aargang, se navnene Margrethe Hansen, Niels Hjorth, K. Thaning i bladets register.

\section{o. Gr. og missionen.}

Rasmus Anker-Møller: Det grundtvigske, folkelige Livssyn og Ydre Mission. Menighedsbladet 1946, 233 f., $244 \mathrm{f}$. 
Rasmus Anker-Moller: Ydre mission og Gr.s forhold dertil. Julebogen. (Udg. af Kirkeligt Samfund.) 1948, 29-41.

Johs. Lauridsen: De grundtvigske Kredse og Hedningsmissionen. Menighedsbladet 1947, $224 \mathrm{f}$.

p. Grundtvigianere, grundtvigske hiem.

C. Christensen-Dalsgaard: Bjørnbakkere og Grundtvigianere. [0: i Randers.] Randers Dagblad 12. april 45.

N. Clausen-Bagge: Grundtvigske Banebrydere. Odense 1941.

- Grundtvigske Banebrydere. Ny Samling. Odense 1944. - Jvf. Hal Koch i Dansk teol. Tidsskr. 1942, 122.

- Grundtvigske Lægmands Ordførere. Odense 1944.

- Grundtvigske Hjem. Odense 1945.

- Rettelser og og Tilføjelser. [0: til forrige.] Odense 1945.

- Grundtvigske Hjem. II. Samling. Odense 1946. Anm. af Sigrid Dahl Rasmussen i Menighedsbl. 1946, 351.

- Grundtvigske Hjem. III. Samling. Odense 1947.

q. Grundtvig-Selskabet og dets publikationer.

»Grundtvig-Selskabet af 8. September 1947« stiftedes nævnte aar og dato i Ribe bispegaard. Bladartikler om selskabets stiftelse: Th. Balslev i Højskolebladet 5. marts 48, V. Grønbæk i Jyllandsposten 7. febr. 48, H. Høirup i Menighedsbladet 1948, 167-169 og i Fyns Tidende 2. novbr. 48, H. Toldberg i Krist. Dagblad 18. febr. 48 og i Sorø Amtstid. 4. aug. 48.

Gr.-Selskabet har indtil udgangen af 1949 udgivet flg. skrifter:

Grundtvig-Studier 1948. Under Redaktion af Henning Hoirup.

Anmeldt bl. a. af P. Augustinus i Menighedsbladet 1949, $270 \mathrm{f} .$, Bjørn Kornerup i Personalhist. Tidsskr. 1949, 172 f., Hal Koch i Dansk teol. Tidsskr. 1948, 248, Paul Krüger i Orbis Litterarum VII (1949), 291.

Grundtvig-Studier 1949. Under Redaktion af Henning Hoirup.

Anmeldtes bl. a. af flg.: G. Albeck i Jyllandsposten 3. oktbr. 49, H. Brix i Berlingske Aftenavis 8. septbr. 49, P. Engberg i Dansk Udsyn 1949, 287 f., Knud Hansen i Information 24. novbr. 49, G. Helms i Fyns Venstreblad 25. septbr. 49 og i Sorø Amtstid. 18. novbr. 49, Chr. KirchhoffLarsen i Børsen 11. septbr. 49, H. Kirk i Land og Folk 20. oktbr. 49, P. M. Mitchell i Scandinavian Studies XVIII (1950), 83-86, N. C. Nissen i Krist. Dagblad 27. septbr. 49.

I Gr.-Selskabets serie »Skrifter udgivet af Grundtvig-Selskabet« er i 194749 udkommet flg.:

I. Henning Hoirup: Gr.s Syn paa Tro og Erkendelse. Modsigelsens Grundsætning som teologisk Aksiom hos Gr. 1949. (Doktordisputats.)

Anmeldelser, se her foran under $I V . d$. 